\title{
University Students' Views on the Education and Teaching of Civilization History: Bayburt University Education Faculty Sample
}

\author{
Mehmet Elban \\ Correspondence: Department of Social Sciences Education, Faculty of Education, Bayburt University, Turkey.
}

Received: July 30, 2017 Accepted: September 7, 2017 Online Published: September 14, 2017

doi:10.11114/jets.v5i10.2560 URL: https://doi.org/10.11114/jets.v5i10.2560

\begin{abstract}
The purpose of this research is to evaluate the teaching and educational activities in the civilization history lesson. The model of the research is the exploratory sequential design from mixed research patterns. The appropriate sampling method was used in the research. The qualitative data of the research were collected from 26 students through a semi-structured interview form. Content analysis was used in the analysis of qualitative data. The quantitative data of the research were obtained by a questionnaire developed as an analysis of the qualitative data of the research. 95 students participated in the questionnaire. Descriptive statistics were used in the analysis of quantitative data In the research, it was understood that the positive attitudes towards the civilization history lesson of the students in the primary school teaching department were caused by curiosity and interest and their negative attitudes were caused by making the students passive and lesson subjects. The civilization history study methods of students are source books, lesson teacher, note-taking, and to work by typing. Reasons of topics which are students easily learn are interest and curiosity, national history and previous information. The reason for the difficulty in learning on some subjects is that there are too many subjects. Interest and curiosity with teaching method and technique are common causes of the success and failure of the students in the civilization history lesson. In addition, students attach great importance to the use of interactive teaching methods and techniques and visual teaching materials in civilization history lesson.
\end{abstract}

Keywords: civilization history lesson, world civilizations, history education, history teaching, primary school teaching

\section{Introduction}

The concept of civilization which differs between the usage in English and French and the usage in German, may have different meanings for western nations. In many cases, the concept of civilization can be intertwined with the concept of culture (Elias, 2004, p. 74). In the civilization history lesson, the ambiguity of the distinction between the concepts of civilization and culture still continues today. However, the civilization history has been a major discipline for a long time with certain content and teaching (Ketchum, 1978, p.3). However, as mentioned in the civilization history, the relation and difference of concept with the concept of culture, the debate about the formation and spread of civilizations has been a topic of discussion before the teaching of the civilization history.

The focal point of these discussions was the Eurocentric historiography. The dramatic experiences of all mankind during the First and Second World Wars also influenced Eurocentric historiography. Along with these bad experiences, new approaches to civilizations emerged both in the work of Spengler and Toynbee and in the Annales school. Speaking of Spengler and Toynbee, Spengler denied the interaction of different cultures by seeing their own unique organism (Spengler, 1997). Toynbee, on the other hand, assessed the relationship between civilizations to a more limited extent (Toynbee, 1978). In particular, the distinction between Helen and Western civilization was criticized by Collingwood (Collingwood, 1996, p. 202).

The focal point of these discussions was the Eurocentric historiography. However, in the early twentieth century, history education and teaching came in on the middle and higher education curriculum in both parts of the Atlantic. But, holistic understanding of history was not adopted and addressing separately the history of other nations were not seen as useful. Although history in Europe was treated as the history of individual nations, each country regarded these nations as a history of repression and exploitation of their own country in a national history line (McNeill, 2015, p.14-15). Against such a picture, Braudel, one of the representatives of the Annales school, stated that the history of different civilizations should be teach (Brauduel, 1996, p.17). Likewise, Toynbee was also advising people to know each other's past regardless of nation, class, and race so that people could live in harmony (Toynbee, 1978, p. 48). 
A voice parallel to the expectations expressed in this political and social atmosphere in the first half of the 21 st century has risen from the United Nations, a national organization. In 1945, UNESCO enacted a "history of mankind" project that would cover all humanity and would not be Eurocentric. The series of books to be prepared was planned to be written by multinational authors, just like the structure of the organization. But reflection of the cold war winds and different expectations has caused this well-intentioned project to delay until 1976. When it comes to the end, although the project has been subject to well-intentioned criticism, it has pioneered other well-intentioned projects. On the other hand, McNeill's work, published in 1963, which deals with cultures interactively and regards them as appreciated values (Duedahl, 2011). While the outlines of the developments in the historiography of civilization were in this way, teaching and teaching in universities as a lesson has become a separate subject.

As a matter of fact, in the 1980s, it was recommended to teach world civilizations in the structure of departments such as social studies and history in the first and second grades of several universities and training centers. In this context, experts on the subject have suggested world civilizations for educational and political reasons. According to this understanding, the lessons of world civilizations will reduce ethnocentrism and offer opportunities for the cultural abundance of the students. On the other hand, the inclusion of different civilizations in textbooks will encourage understanding of what civilization means, and students will understand humanistic knowledge and world cultural heritage (Sjoquist, 2006, p.36-38).

On the other hand, diffusionism and thematic approach can be mentioned in the education of world civilizations. The civilizations studied in the diffusionist approach are considered as cultural centers. This understanding want to provide that students understand the ways in which people embrace values, beliefs, art, politics, and technology in relation to the cultural centers. In the thematic model, the choice of subjects is possible. The thematic approach focuses on the cultural universality. It is based on the understanding that cultural requirements are always shared among all people. As an advantage of thematic conception, subjects are not confined to a certain time. The issues may be related to the present and may also be related to centuries ago (Sjoquist, 2006, p.39).

Civilization and culture issues are also used as a complementary activity teaching to foreign students of a country in teaching own language of the country. This facilitates adaptation of foreign students to the cultural and world perception of the host country (Gafu and Trifan, 2015). In addition, if the diachronic approach (handling in the historical development of language) is adopted in language learning, teaching the historical development of civilization is recommended, and if the synchronic approach (taking into account the current view of language) is adopted, teaching modern civilization is recommended (Ketchum, 1978, p.4).

At the level of primary education, stories and teaching techniques of civilizations are seen as an effective approach (Fuoco, 1996). It has also been found that creative drama activities at the primary education level are effective in teaching civilizations (Kartal, 2009). In this context, in this research, the civilization history lesson was examined in terms of the learners who received education and training. In other words, the students who have taken the civilization history lesson, which is included in the classroom teaching program of the universities, are evaluated in terms of education and teaching in this research. In this context, the following questions were searched in the research:

1. How do university students evaluate civilization history education in terms of personal and professional development?

2. How do university students evaluate the civilization history education?

3. How do university students evaluate teaching of the civilization history?

4. How does the quantitative data obtained from the the study support qualitative findings?

\section{Method}

\subsection{Model of Research}

The model of the research is the exploratory sequential design from mixed research patterns. In the exploratory sequential design, firstly, qualitative data is collected and analyzed, a data collection tool is developed utilizing these findings and data is collected again with the quantitative step (Creswell, 2017, p. 40). The mentioned processes have been followed as models in the research. In the qualitative part of the study, Phenomenology method was used as qualitative research methods. The aim of the phenomological research is to reveal the lived experiences of the individuals involved in the research (Johnson and Christensen, 2014, p.383). The quantitative part of the study was designed in accordance with the survey method. The survey method is defined as a method of collecting data through interviews or surveys (Fraenkel, Wallen and Hyun, 2015, p. 391) and aiming to reveal the general view of the group.

\subsection{Working Group}

The study group of the study consisted of students who had studied at Bayburt University and had taken the civilization 
history lesson . In this context, 26 first-year students from Bayburt university, Primary School Teaching Department were selected. 14 of these students are girls and 12 of them are male. Volunteerism is the basis for students' participation in the research. The study group of the quantitative dimension of the research is composed of a total of 95 students who are studying at Bayburt University and who have taken the civilization history lesson. 55 of these students are girls; 40 of them are male.

\subsection{Data Collection Tools and Analysis}

In the study, interview technique was used as data collection technique. For this purpose, a semi-structured interview form was prepared. The semi-structured interview form prepared to answer research problems consists of 11 open ended questions. In order to ensure the validity of the interview form, the opinions of 3 experts were obtained so that the interview form was finalized. The duration of negotiations is between 10 and 30 minutes

Content analysis was used in the analysis of the data obtained from participants. The answers of the participants to the questions in the semi-structured interview form were recorded on the voice recorder and then deciphered. The textual answers are depicted numerically by creating themes and analysis units within the framework of research problems.

Coding has been coded by two experts to ensure reliability in content analysis. The codings were $87 \%$ compatible. Code compliance is considered to be sufficient if the ratio is $70 \%$ or higher and shows a high degree of compliance between the interrater (Miles and Huberman, 2015, p.64; Muijs, 2004, p. 73). It has been discussed on the non-compatible codes and decided that some codes will not be included in the research and some codes will be merged. In the relationship building phase, the codes have been categorized under the class according to their relations with each other. The results obtained have been shown as frequency.

A questionnaire was developed as a result of the analysis of data obtained from the qualitative dimension. Expert opinions were sought for the questionnaire's validity study. Firstly, an item pool was formed for the questionnaire. The created item pool was presented to 4 experts' opinions, one in Turkish and the other three in the field of history educators, and their suitability was checked for clarity. After some items were changed in line with expert opinions, it was concluded that the survey was appropriate in terms of coverage. Thus, a 66-item questionnaire was formed.

SPSS 22 package program was used for analysis of quantitative data. Quantitative data were evaluated with mean and standard deviation. The evaluation intervals of the material are "I totally disagree" between 1.00-1.80; "I disagree" between 1.81-2.60; Between 2.61-3.40 "I am undecided"; "I agree" between 3.41-4.20 and "I totally agree" between 4.21-5.00.

\section{Results}

Qualitative and quantitative data are presented together in the study. Table 1 shows the results of how university students evaluate civilizational history education in personal and professional terms.

Table 1. Personal and professional contribution of civilization history education

\begin{tabular}{|c|c|c|c|c|c|c|}
\hline \multirow{2}{*}{$\begin{array}{l}\text { Qualitative Data } \\
\text { Evaluations }\end{array}$} & \multicolumn{3}{|r|}{ Quantitative Data } & \multirow[b]{2}{*}{$\bar{X}$} & \multirow[b]{2}{*}{ SS } & \multirow[b]{2}{*}{ Level } \\
\hline & $\mathrm{f}$ & Surv & ey items & & & \\
\hline $\begin{array}{l}\text { General culture and } \\
\text { multidisciplinary knowledge }\end{array}$ & 13 & $\mathrm{~m} 1$ & $\begin{array}{l}\text { Civilization history education provides } \\
\text { general culture and multidisciplinary } \\
\text { information }\end{array}$ & 4.11 & .74 & I agree \\
\hline Professional field knowledge & 11 & $\mathrm{~m} 2$ & $\begin{array}{l}\text { Civilization history education give } \\
\text { professional field knowledge }\end{array}$ & 3.61 & .87 & I agree \\
\hline $\begin{array}{l}\text { New information and different } \\
\text { perspectives }\end{array}$ & 6 & $\mathrm{~m} 3$ & $\begin{array}{l}\text { Civilization history education provides new } \\
\text { information and different perspectives }\end{array}$ & 4.09 & .76 & I agree \\
\hline Lessons from civilizations & 5 & $\mathrm{~m} 4$ & $\begin{array}{l}\text { Civilization history education provides us to } \\
\text { take lessons from civilizations. }\end{array}$ & 3.95 & .87 & I agree \\
\hline $\begin{array}{l}\text { Introducing the person to own } \\
\text { civilization and providing him to be } \\
\text { proud of it }\end{array}$ & 4 & $\mathrm{~m} 5$ & $\begin{array}{l}\text { Civilization history education introduces the } \\
\text { person to own civilization and provide him } \\
\text { to be proud of it }\end{array}$ & 4.22 & .96 & $\begin{array}{l}\text { I totally } \\
\text { agree }\end{array}$ \\
\hline
\end{tabular}

In the qualitative data in Table 1, students have listed the contribution of civilized history education to their personal and professional education as "general culture and multidisciplinary knowledge $(\mathrm{f}=13)$ ", "professional field knowledge $(f=11)$ ","new information and different perspectives $(f=6)$ ", "lessons from civilizations" $(f=5)$ and "introducing the individual to his own civilization and making him proud with it $(f=4)$ ". This result shows that students think that 
civilizational history education contributed to their personal and professional education. Because the quantitative data of the research supports this vision at the level of "I agree and I fully agree". The items with the highest participation levels are "Civilization history education introduces the person to own civilization and provide him to be proud of it" ( $\overline{\mathrm{X}}=4.22$, $\mathrm{SS}=.96)$ and "Civilization history education provides general culture and multi-disciplinary knowledge" $(\overline{\mathrm{X}}=4.11$, $\mathrm{SS}=.74$ ). It can also be expressed that qualitative data and quantitative data on the contribution of the civilization history lesson to the personal and professional development of the students support each other at a high level. In the research, the results of the attitudes and reasons for the civilization history of university students are shown in Table 2 .

Table 2. Evaluations on the attitudes and reasons of the history education of civilization

\begin{tabular}{|c|c|c|c|c|c|}
\hline \multirow{2}{*}{$\begin{array}{c}\text { Qualitative Data } \\
\text { Positive attitudes } \\
\mathrm{f}=20 \text { reasons }\end{array}$} & \multirow[b]{2}{*}{$\mathrm{f}$} & Quantitative Data & \multicolumn{3}{|c|}{ Student $(\mathrm{n}=95)$} \\
\hline & & Questionnaire items & $\bar{X}$ & SS & Level \\
\hline Curiosity and interest & 10 & $\begin{array}{l}\text { I like the civilization history as it provides } \\
\text { general cultural information }\end{array}$ & 3.44 & 1.09 & I agree \\
\hline $\begin{array}{l}\text { Providing general cultural } \\
\text { information }\end{array}$ & 9 & $\begin{array}{l}\text { I like civilization history as it provides } \\
\text { general cultural information }\end{array}$ & 3.60 & 1.00 & I agree \\
\hline Professional development & 5 & $\begin{array}{l}\text { I like the civilization history as it contributes } \\
\text { to my professional development }\end{array}$ & 3.19 & .94 & $\begin{array}{c}\text { I'm } \\
\text { undecided }\end{array}$ \\
\hline $\begin{array}{l}\text { The teacher's teaching method } \\
\text { and technique }\end{array}$ & 4 & $\begin{array}{ll}\text { Teacher's effective teaching method and } \\
\text { m9 technique helped to dislike civilization } \\
\text { history }\end{array}$ & 3.34 & 1.10 & $\begin{array}{c}\text { I'm } \\
\text { undecided }\end{array}$ \\
\hline Learning the origins of words & 1 & $\begin{array}{ll}\text { m10 like the civilization history lesson as it } \\
\text { teaches the origins of the words }\end{array}$ & 3.16 & 1.02 & $\begin{array}{c}\text { I'm } \\
\text { undecided }\end{array}$ \\
\hline Negative Attitudes $\mathrm{f}=2$ reason & $\mathrm{f}$ & & & & \\
\hline Making the student passive & 4 & $\begin{array}{l}\text { I do not like the civilization history as it } \\
\text { makes the student passive }\end{array}$ & 3.43 & 1.21 & I agree \\
\hline Unstable attitudes $\mathrm{f}=4$ reasons & $\mathrm{f}$ & & & & \\
\hline $\begin{array}{l}\text { Some of the subjects are liked } \\
\text { and some are not liked }\end{array}$ & 2 & $\begin{array}{l}\text { My love for the civilization history varies } \\
\text { depending on the subject of lesson }\end{array}$ & 3.84 & .95 & I agree \\
\hline
\end{tabular}

According to the qualitative data are given in Table 2, the majority of the students developed a positive attitude towards the civilization history education $(\mathrm{f}=20)$. Students have listed the reasons for the positive attitudes towards the civilization history education as the most "curiosity and interest $(\mathrm{f}=10)$ " and "providing general cultural knowledge $(\mathrm{f}=$ 9)". The opinions of the students on the questionnaire of the research for these reasons are at the level of "I agree". These items are "I like civilization history because I have interest and curious in the civilization history" $(\overline{\mathrm{X}}=3.44, \mathrm{SS}=$ 1.09 ) and "I like the civilization history as it provides general cultural information" ( $\overline{\mathrm{X}}=3.60, \mathrm{SS}=1.00)$.

According to Table 2, the students explained that the negative attitudes towards the civilization history lesson were caused by making the students passive $(\mathrm{f}=2)$. Students expressed opinions on the level of "I agree" in the questionnaire on the reason related to the negative attitude towards the civilization history lesson. This item in the questionnaire is "I do not like the civilization history as it makes the student passive" $(\overline{\mathrm{X}}=3.43$, SS $=1.21)$ ". In addition, the students indicated the reasons for the undecided attitudes towards the lesson in the qualitative data as "Some of the subjects are liked and some are not liked" $(\mathrm{f}=4)$. Students participated in these reason at the level of "I participate" in the questionnaire. This item is "My love for the civilization history varies depending on the subject of lesson $\left(\mathrm{X}^{-}=3.84\right.$, $\mathrm{SS}=.95)$ ). In the research, the views of university students on the reasons for not having difficulties in learning the civilization history are presented in Table 3. 
Table 3. Reasons why students do not have difficulty in learning the civilization history

\begin{tabular}{|c|c|c|c|c|c|}
\hline Qualitative Data & & Quantitative Data & Stude & $\mathrm{nt}(\mathrm{n}=$ & \\
\hline $\begin{array}{l}\text { difticulty in learnıng } \\
\qquad \begin{array}{l}\mathrm{F}=9 \\
\text { reasons }\end{array}\end{array}$ & $\mathrm{f}$ & Questionnaire items & $\bar{X}$ & SS & Level \\
\hline Interest and Curiosity & $7 \mathrm{~m} 13$ & $\begin{array}{l}\text { I did not have any difficulty in learning because I have } \\
\text { interest and curious in the civilization history. }\end{array}$ & 3.15 & 1.04 & $\begin{array}{c}\text { I'm } \\
\text { undecided }\end{array}$ \\
\hline Previous information & $7 \mathrm{~m} 14$ & $\begin{array}{l}\text { I did not have any difficulty in learning this lesson } \\
\text { thanks to my previous knowledge in the civilization } \\
\text { history. }\end{array}$ & 3.24 & 1.06 & $\begin{array}{c}\text { I'm } \\
\text { undecided }\end{array}$ \\
\hline $\begin{array}{l}\text { Studying well for the } \\
\text { lesson }\end{array}$ & $2 \mathrm{~m} 15$ & $\begin{array}{l}\text { I did not have any difficulty in learning this lesson } \\
\text { because I studied well on the civilization history. }\end{array}$ & 3.09 & 1.03 & $\begin{array}{c}\text { I'm } \\
\text { undecided }\end{array}$ \\
\hline
\end{tabular}

According to the qualitative data are given in Table 3, 9 of the students did not have difficulty in learning the lesson ( $\mathrm{f}=$ 9). Those who do not have difficulty in learning have listed these as interest and curiosity ( $f=7$ ), prior knowledge ( $f=7$ ) and studying well for the lesson $(\mathrm{f}=2)$. Students participated in these reasons at the level of "I am undecided" in the $\mathrm{m} 13, \mathrm{~m} 14$ and $\mathrm{m} 15$ of the questionnaire items which constituted the quantitative dimension of the research $(\mathrm{m} 13$, $\overline{\mathrm{X}}=3.15 ; \mathrm{m} 14, \overline{\mathrm{X}}=3.24 ; \mathrm{m} 15, \overline{\mathrm{X}}=3.09$ ). In the research, the views of university students on the reasons for the difficulty in learning the civilization history are presented in Table 4.

Table 4. Reasons why students have difficulty in learning the civilization history

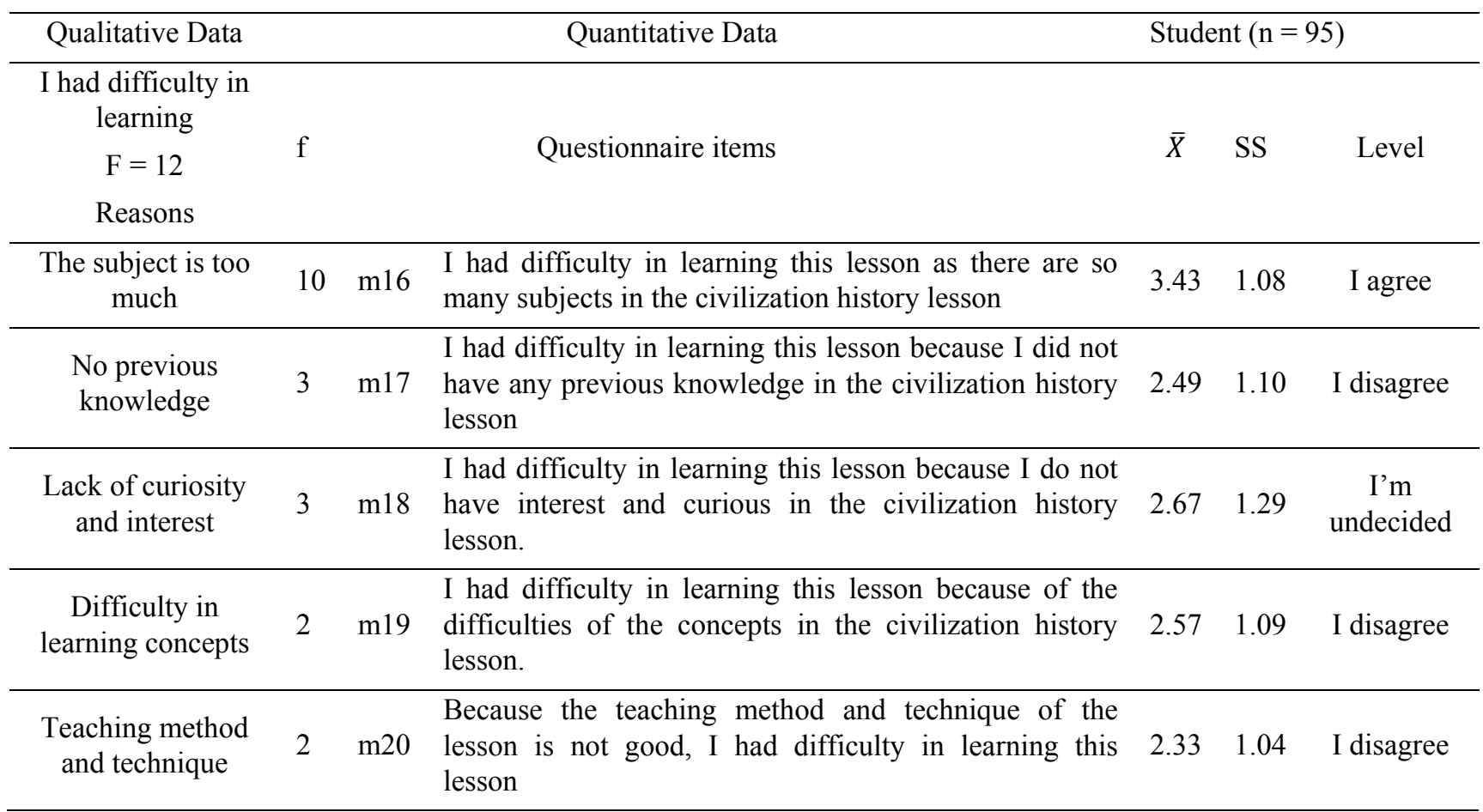

According to the qualitative data are given in Table 4, 12 of the students had difficulty in learning ( $\mathrm{f}=12$ ). Those who have difficulty in learning have listed these as the subject is too much $(f=10)$, lack of previous information $(f=3)$, interest and incuriousness ( $f=3$ ), difficulty in learning concepts $(f=2)$, teaching method and technique ( $f=2)$. In the quantitative aspect of the research, students participated in m16 only at the level of "I agree" from the items of the questionnaire on these reasons. This item is "I had difficulty in learning this lesson as there are so many subjects in civilization history education" ( $\overline{\mathrm{X}}=3.43, \mathrm{SS}=.1 .08)$. In the research, the views of university students on the reasons why university students have some difficulty in learning the civilization history lesson are presented in Table 5. 
Table 5. Reasons why students have partially difficulties in learning the civilization history lesson

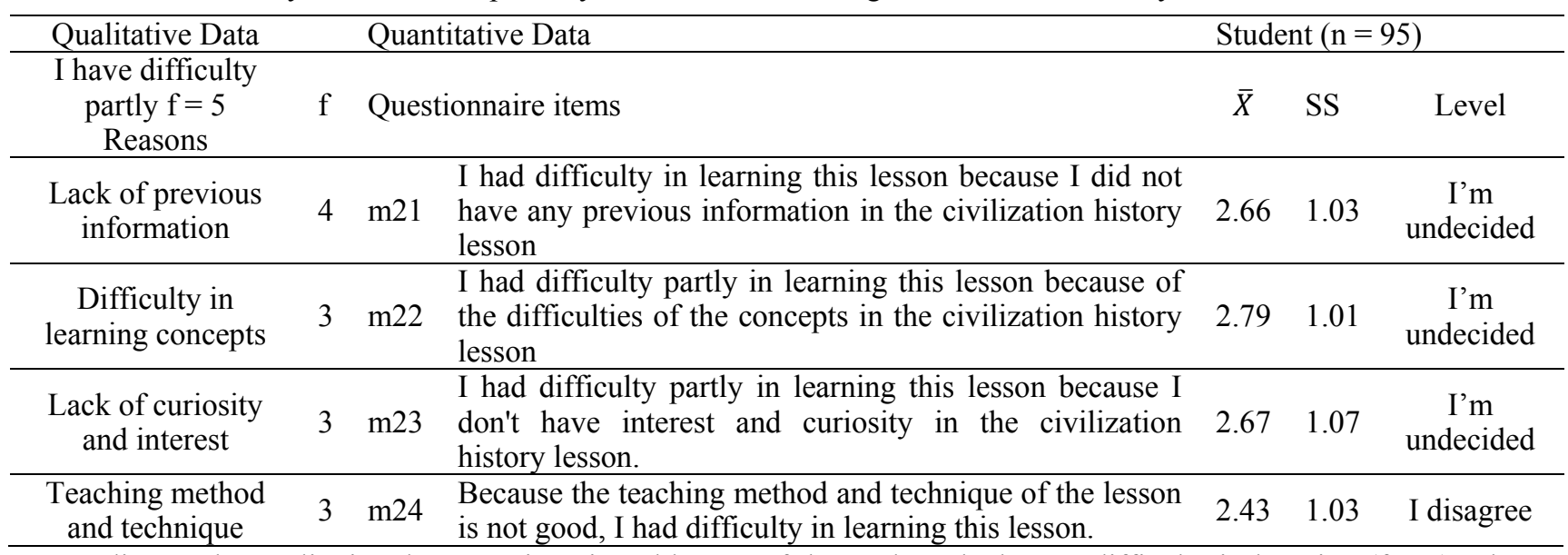

According to the qualitative data are given in Table 5, 5 of the students had some difficulty in learning $(f=5)$. Those who have difficulty in learning have listed the reasons for this as no lack of previous information $(\mathrm{f}=4)$, Difficulty in learning concepts $(\mathrm{f}=3)$, lack of curiosity and interest $(\mathrm{f}=3)$, teaching method and technique $(\mathrm{f}=3)$. Students participated in these reasons at the level of "I am undecided" in the $\mathrm{m} 2$., m22. and m23 and at the level of "I agree" in m24. of the questionnaire items which constituted the quantitative dimension of the research (m21., $\bar{X}=2.66 ; \mathrm{m} 22 ., \overline{\mathrm{X}}=2.79$; m23., $\overline{\mathrm{X}}=2.67 ; \mathrm{m} 24 ., \overline{\mathrm{X}}=2.43$ ). In the research, Results showing the study techniques of university students in the civilization history lesson are presented in Table 6.

Table 6. Study techniques of students in the civilization history lesson

\begin{tabular}{cclllll}
\hline $\begin{array}{c}\text { Qualitative Data } \\
\begin{array}{c}\text { Studying techniques } \\
\text { of Students }\end{array}\end{array}$ & $\mathrm{f}$ & \multicolumn{2}{l}{ Questionnaire items } & $\bar{X}$ & $\mathrm{SS}$ & Level \\
\hline $\begin{array}{c}\text { Source book and } \\
\text { lesson teacher }\end{array}$ & 14 & $\mathrm{~m} 25$ & $\begin{array}{l}\text { I have studied the civilization history lesson by using } \\
\text { the resource book and listening to the teacher }\end{array}$ & 4.00 & .89 & I agree \\
\hline Note-Taking & 12 & $\mathrm{~m} 26$ & $\begin{array}{l}\text { I have studied the civilization history lesson by } \\
\text { taking note }\end{array}$ & 3.52 & 1.24 & I agree \\
\hline Research & 3 & $\mathrm{~m} 27$ & $\begin{array}{l}\text { I have studied the civilization history lesson by doing } \\
\text { research }\end{array}$ & 2.63 & 1.18 & $\begin{array}{c}\text { I'm } \\
\text { undecided }\end{array}$ \\
\hline Working by writing & 3 & $\mathrm{~m} 28$ & $\begin{array}{l}\text { I have studied the civilization history lesson by } \\
\text { writing }\end{array}$ & 3.52 & 1.19 & I agree \\
\hline Repeating & 3 & $\mathrm{~m} 29$ & $\begin{array}{l}\text { I have studied the civilization history lesson by } \\
\text { repeating }\end{array}$ & 3.33 & 1.16 & $\begin{array}{c}\text { I'm } \\
\text { undecided }\end{array}$ \\
\hline Multiple books & 1 & $\mathrm{~m} 30$ & $\begin{array}{l}\text { I have studied the civilization history lesson by } \\
\text { reading multiple books }\end{array}$ & 2.56 & 1.17 & I disagree \\
\hline
\end{tabular}

According to the qualitative data are given in Table 6, study techniques of students in the civilization history lesson were listed as the source book and lesson teacher $(\mathrm{f}=14)$, note-taking $\mathrm{f}=12$ ), research $(\mathrm{f}=3)$, studying by writing $(\mathrm{f}=3$ ), repeating $(\mathrm{f}=3)$ and multiple books $(\mathrm{f}=1)$. Students participated at the level of "I agree" in the $\mathrm{m} 25 ., \mathrm{m} 26$.and $\mathrm{m} 28$. and at the level of "I am undecided" in $\mathrm{m} 27$. and $\mathrm{m} 29$. of the questionnaire items which applied to study techniques (m25, $\overline{\mathrm{X}}=4.00 ; \mathrm{m} 26, \overline{\mathrm{X}}=3.52 ; \mathrm{m} 27, \overline{\mathrm{X}}=2.63 ; \mathrm{m} 28, \overline{\mathrm{X}}=3.52 ; \mathrm{m} 29, \overline{\mathrm{X}}=3.33 ; \mathrm{m} 30, \overline{\mathrm{X}}=2.56$ ). In the research, results showing reasons for students to learn some subjects easily in the civilization history lesson are presented in Table 7. 
Table 7. Reasons for students to learn some subjects easily in the civilization history lesson

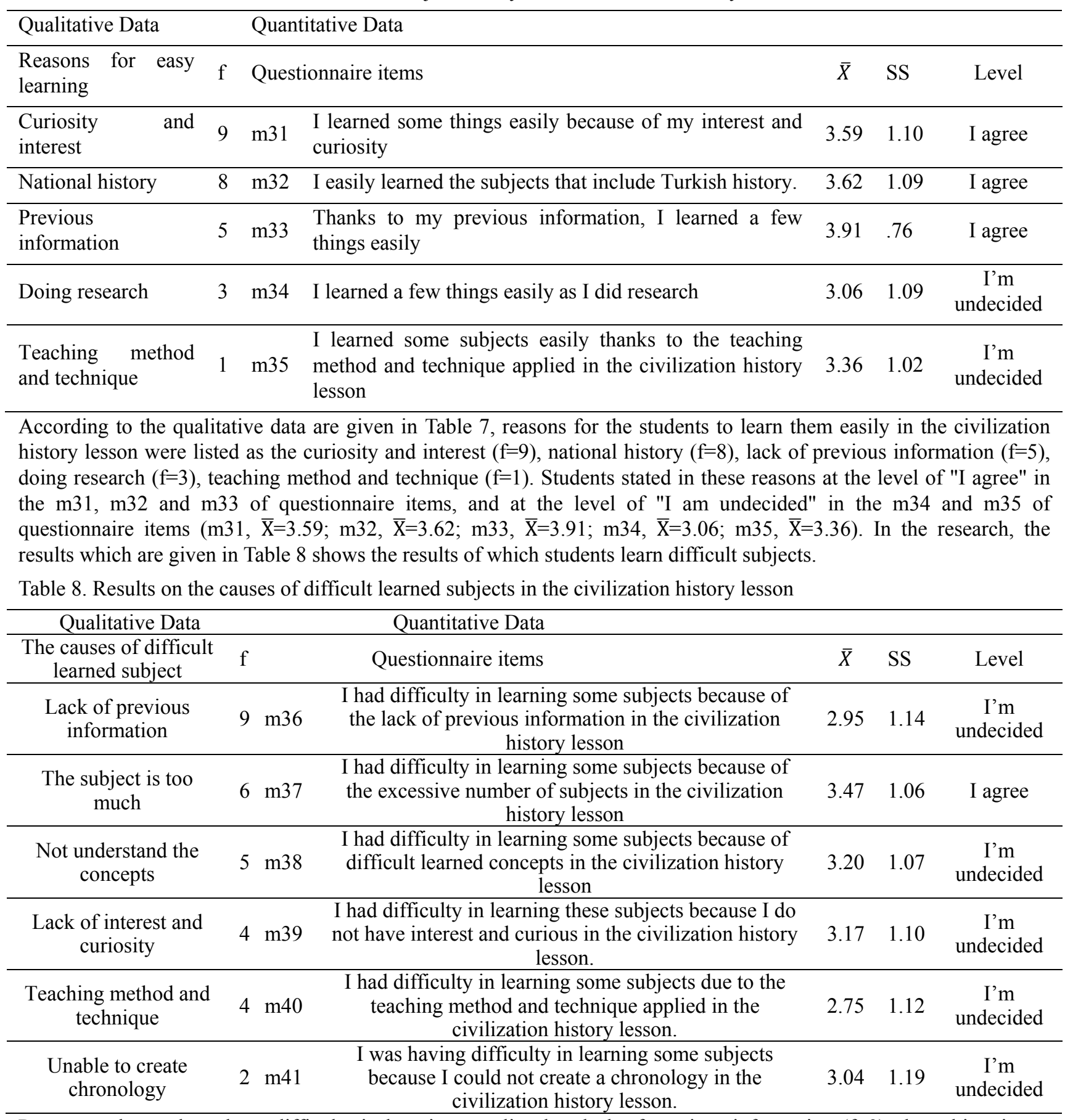

Reasons, why students have difficulty in learning, are listed as lack of previous information ( $\mathrm{f}=9$ ), the subject is too much $(\mathrm{f}=6)$, lack of understand the concepts $(\mathrm{f}=5)$, lack of interest and curiosity $(\mathrm{f}=4)$, teaching method and technique $(\mathrm{f}=4)$, unable to create chronology $(\mathrm{f}=2)$ in Table 8 . According to article $\mathrm{m} 37$ (I had difficulty in learning some subjects because of the excessive number of subjects in the civilization history lesson), which is the provision of quantitative data for reasons of excess of subjects indicated by students in qualitative data, students have expressed their opinions at the level of "I agree" (m37, $\bar{X}=3.47$ ). For other reasons derived from qualitative data, students did not report opposing views on quantitative data, but they have participated the level of "I am undecided". The views about university students' reasons for success in the civilization history lesson were presented in Table 9 in the research. 
Table 9. Results on the reasons for success in the civilization history lesson

\begin{tabular}{|c|c|c|c|c|c|c|}
\hline \multicolumn{3}{|c|}{ Qualitative Data } & \multicolumn{4}{|l|}{ Quantitative Data } \\
\hline $\begin{array}{l}\text { Reasons for } \\
\text { success }\end{array}$ & $\mathrm{f}$ & & Questionnaire items & $\bar{X}$ & SS & Level \\
\hline $\begin{array}{l}\text { Teaching } \\
\text { method and } \\
\text { technique }\end{array}$ & 12 & $\mathrm{~m} 42$ & $\begin{array}{l}\text { The teaching method and technique applied in } \\
\text { the civilization history lesson affects the success } \\
\text { of this lesson }\end{array}$ & 4.29 & .86 & $\begin{array}{l}\text { I totally } \\
\text { agree }\end{array}$ \\
\hline $\begin{array}{l}\text { Interest and } \\
\text { curiosity }\end{array}$ & 11 & $\mathrm{~m} 43$ & $\begin{array}{l}\text { The interest and curiosity in the civilization } \\
\text { history lesson affects the success of this lesson }\end{array}$ & 4.39 & .71 & $\begin{array}{c}\text { I totally } \\
\text { agree }\end{array}$ \\
\hline Doing again & 3 & $\mathrm{~m} 44$ & $\begin{array}{l}\text { Studying by doing repeating in the civilization } \\
\text { history lesson affects the success }\end{array}$ & 4.33 & .78 & $\begin{array}{c}\text { I totally } \\
\text { agree }\end{array}$ \\
\hline $\begin{array}{l}\text { Studying } \\
\text { lessons }\end{array}$ & 2 & $\mathrm{~m} 45$ & $\begin{array}{l}\text { Studying the civilization history lesson } \\
\text { influences the success of this lesson }\end{array}$ & 4.39 & .73 & $\begin{array}{l}\text { I totally } \\
\text { agree }\end{array}$ \\
\hline
\end{tabular}

The reasons for the success of the students in the civilization history lesson are listed as the teaching method and technique ( $\mathrm{f}=12$ ), interest and curiosity ( $\mathrm{f}=11)$, doing again $(\mathrm{f}=3)$, studying lessons $(\mathrm{f}=2)$. All the reasons for which they stated in the qualitative data, the students gave the opinion "I totally agree" on the relevant items in the questionnaire in the quantitative part of the research (m42., $\bar{X}=4.29 ; \mathrm{m} 43 ., \bar{X}=4.39 ; \mathrm{m} 44 ., \overline{\mathrm{X}}=4.33$ and $\mathrm{m} 45 ., \overline{\mathrm{X}}=4.39$ ). The views of university students on the causes of failure in the civilization history lesson were presented in Table 10 in the research.

Table 10. Results on the causes of failure in the civilization history lesson

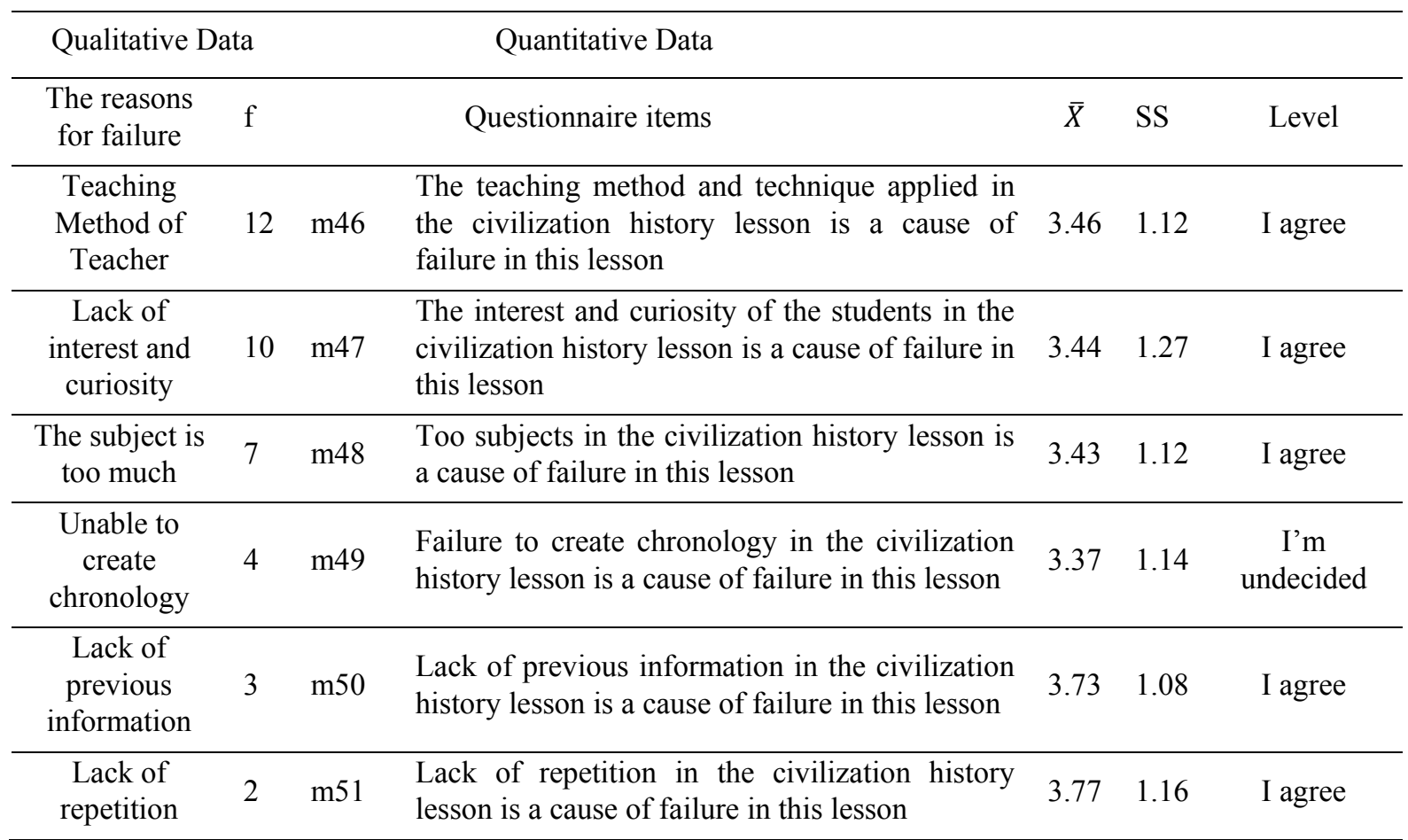

The reasons for failure of the students in the civilization history lesson are listed as the teaching method of teacher $(\mathrm{f}=12)$, interest and curiosity ( $\mathrm{f}=10)$, the subject is too much $(\mathrm{f}=7)$, unable to create chronology $(\mathrm{f}=4)$, lack of previous information $(\mathrm{f}=3)$ and lack of repetition $(\mathrm{f}=2)$. Students on the reasons stated in the qualitative data reported opinions the relevant items ( $\mathrm{m} 46 ., \overline{\mathrm{X}}=3.46 ; \mathrm{m} 47 ., \overline{\mathrm{X}}=3.44 ; \mathrm{m} 48 ., \overline{\mathrm{X}}=3.43 ; \mathrm{m} 50 ., \overline{\mathrm{X}}=3.73$ and $\mathrm{m} 51 ., \overline{\mathrm{X}}=3.77)$ in the questionnaire in the quantitative part of the research at the level of "I agree". They only expressed their opinion at the level of "Undecided" in article $\mathrm{m} 49$ ( $\mathrm{m} 49 ., \overline{\mathrm{X}}=3.37)$. In the research, the opinions of the students on the teaching method and technique in the civilization history lessons are presented in Table 11. 
Table 11. Views on civilization history teaching method and technique

\begin{tabular}{|c|c|c|c|c|c|c|}
\hline Qualitative Data & & & Quantitative Data & & & \\
\hline $\begin{array}{lr}\text { Views on } & \text { teaching } \\
\text { method } & \text { and } \\
\text { technique } & \\
\end{array}$ & $\mathrm{f}$ & & Questionnaire items & $\bar{X}$ & SS & Level \\
\hline $\begin{array}{l}\text { Story-style narration } \\
\text { should be used }\end{array}$ & 11 & $\mathrm{~m} 52$ & $\begin{array}{l}\text { Civilization history lessons should be } \\
\text { told in story style }\end{array}$ & 3.95 & 1.11 & I agree \\
\hline $\begin{array}{l}\text { Student-centered } \\
\text { teaching should be } \\
\text { used }\end{array}$ & 3 & $\mathrm{~m} 53$ & $\begin{array}{l}\text { Student-centered teaching should be } \\
\text { done in the civilization history lesson }\end{array}$ & 4.05 & 1.05 & I agree \\
\hline Questions- answers & 4 & m54 & $\begin{array}{l}\text { Question-and-answer technique should } \\
\text { be used in the civilization history } \\
\text { lesson }\end{array}$ & 3.93 & .97 & I agree \\
\hline $\begin{array}{l}\text { Phenomenons should } \\
\text { be taught }\end{array}$ & 3 & m55 & $\begin{array}{l}\text { Phenomenons should be taught in the } \\
\text { civilization history lesson }\end{array}$ & 3.88 & .80 & I agree \\
\hline Deduction method & 2 & m56 & $\begin{array}{l}\text { The deduction method should be used } \\
\text { in the civilization history lesson }\end{array}$ & 3.79 & 1.00 & I agree \\
\hline
\end{tabular}

In Table 11, students' opinions on teaching method and technique in the civilization history lesson were found as story-style narration should be used $(\mathrm{f}=11)$, student-centered teaching should be used $(\mathrm{f}=3$ ), questions- answers $(\mathrm{f}=4)$, phenomenons should be taught $(\mathrm{f}=3)$ and deduction method $(\mathrm{f}=2)$ in the qualitative data of the research. For all the reasons mentioned in the qualitative data, the students reported opinions at the level of "I agree" the relevant items in the questionnaire in the quantitative part of the research (m52., $\bar{X}=3.95 ; \mathrm{m} 53 ., \bar{X}=4.05 ; \mathrm{m} 54 ., \bar{X}=3.93 ; \mathrm{m} 55 ., \overline{\mathrm{X}}=3.88$ and $\mathrm{m} 56 ., \overline{\mathrm{X}}=3.79)$. In the research, the opinions of the students on the teaching material in the civilization history lesson are presented in Table 12.

Table 12. Suggestion results on the teaching material in the civilization history lesson

\begin{tabular}{cccllll}
\hline $\begin{array}{c}\text { Qualitative Data } \\
\text { Views on teaching } \\
\text { material }\end{array}$ & $\mathrm{f}$ & & Questionnaire items & $\overline{\text { Quantitative Data }}$ & $\mathrm{SS}$ & Level \\
\hline $\begin{array}{c}\text { Documentary should } \\
\text { be used }\end{array}$ & 15 & $\mathrm{~m} 57$ & $\begin{array}{l}\text { Documentary often should be used in the } \\
\text { civilization history lesson }\end{array}$ & 3.79 & 1.00 & I agree \\
\hline $\begin{array}{c}\text { Movies should be } \\
\text { used }\end{array}$ & 13 & $\mathrm{~m} 58$ & $\begin{array}{l}\text { Movies should be used in the civilization } \\
\text { history lesson }\end{array}$ & 4.18 & .72 & I agree \\
\hline $\begin{array}{c}\text { Power point } \\
\text { presentation should } \\
\text { be used }\end{array}$ & 12 & $\mathrm{~m} 59$ & $\begin{array}{l}\text { Power point presentation should be used } \\
\text { in the teaching of the civilization history } \\
\text { lesson }\end{array}$ & 3.63 & .95 & I agree \\
\hline $\begin{array}{c}\text { Pictures and } \\
\text { photographs should } \\
\text { be used }\end{array}$ & 9 & $\mathrm{~m} 60$ & $\begin{array}{l}\text { Pictures and photographs should be used } \\
\text { in the teaching of the civilization history } \\
\text { lesson }\end{array}$ & 4.29 & .60 & I totally \\
agree
\end{tabular}

In Table 12, students' opinions on teaching material in the civilization history lesson were found as "documentary should be used ( $\mathrm{f}=15)$, movies should be used $(\mathrm{f}=13)$, power point presentation should be used ( $\mathrm{f}=12$ ), pictures and photographs should be used $(\mathrm{f}=9)$, models should be used $(\mathrm{f}=4)$ and the chronology chart should be used ( $\mathrm{f}=3$ )" in the qualitative data of the research. For all the reasons mentioned in the qualitative data, the students reported opinions at the level of "I agree" and "I totally agree" the relevant items in the questionnaire in the quantitative part of the research (m57., $\bar{X}=3.79 ; \mathrm{m} 58 ., \bar{X}=4.18 ; \mathrm{m} 59 ., \overline{\mathrm{X}}=3.63 ; \mathrm{m} 60 ., \overline{\mathrm{X}}=4.29 ; \mathrm{m} 61 ., \overline{\mathrm{X}}=3.86$ and $\mathrm{m} 62 ., \overline{\mathrm{X}}=3.87$ ). In the research, the opinions of the students on the events in the civilization history lesson are presented in Table 13. 
Table 13. Suggestion results on the activities in the civilization history lesson

\begin{tabular}{|c|c|c|c|c|c|c|}
\hline \multicolumn{2}{|c|}{ Qualitative Data } & \multicolumn{2}{|r|}{ Quantitative Data } & \multirow[b]{2}{*}{$\bar{X}$} & \multirow[b]{2}{*}{ SS } & \multirow[b]{2}{*}{ Level } \\
\hline $\begin{array}{l}\text { Opinions } \\
\text { about the } \\
\text { events }\end{array}$ & $\mathrm{f}$ & Ques & nnaire items & & & \\
\hline $\begin{array}{l}\text { Drama should } \\
\text { be done }\end{array}$ & 12 & $\mathrm{~m} 63$ & $\begin{array}{l}\text { Drama should be done frequently in the } \\
\text { teaching of the civilization history lesson }\end{array}$ & 3.41 & 1.07 & I agree \\
\hline $\begin{array}{l}\text { Museum trip } \\
\text { should be } \\
\text { done }\end{array}$ & 6 & $\mathrm{~m} 64$ & $\begin{array}{l}\text { Museum tour should be done in the teaching of } \\
\text { the civilization history lesson }\end{array}$ & 4.08 & .97 & I agree \\
\hline $\begin{array}{c}\text { Students } \\
\text { should prepare } \\
\text { presentation }\end{array}$ & 5 & $\mathrm{~m} 65$ & $\begin{array}{l}\text { Students should prepare the presentation in the } \\
\text { teaching of the civilization history lesson }\end{array}$ & 3.17 & 1.29 & $\begin{array}{c}\text { I'm } \\
\text { undecided }\end{array}$ \\
\hline $\begin{array}{l}\text { Expert person } \\
\text { conference } \\
\text { should be held }\end{array}$ & 4 & $\mathrm{~m} 66$ & $\begin{array}{l}\text { Expert conference should be held frequently in } \\
\text { the teaching of the civilization history lesson }\end{array}$ & 3.44 & 1.11 & I agree \\
\hline
\end{tabular}

In Table 13, students' opinions on the activities in the civilization history lesson were found as "drama should be done $(\mathrm{f}=12)$, museum trip should be done $(\mathrm{f}=6)$, students should prepare presentation $(\mathrm{f}=5)$ and expert person conference should be held $(\mathrm{f}=4)$ " in the qualitative data of the research. For the reasons mentioned in the qualitative data, the students expressed their views at the level of "I agree" the relevant items (m63., $\bar{X}=3.41$; m64., $\bar{X}=4.08$ and m66., $\bar{X}=3.44)$ in the questionnaire in the quantitative part of the research. They only expressed an opinion at the level of "Undecided" in article $\mathrm{m} 65$ (m65., $\mathrm{X}=3.44)$.

\section{Discussion}

Students in this research think that the civilization history lesson provides general cultural and multidisciplinary knowledge, provides professional field knowledge, develops new information and different perspectives, enables them to learn from civilizations and proud of them by introducing their own civilization. The data obtained here are fully supported by quantitative data. These findings obtained in the research are generally evaluated among the aims of the new history teaching (Demircioğlu, 2006). In this context, it can be considered that the civilization history lesson is aimed at the purposes of teaching new history. In addition, Akbaba, Demirtaş, Birbudak and Kılcan (2014, p.220) have found that most of the students are interested in this lesson in their research on university students' attitudes toward revolutionary history. This result supports the findings obtained in the research.

In this research, the students explained the causes of positive attitudes towards civilization history lesson as curiosity and interest and general cultural knowledge. It can also be said that qualitative data and quantitative data toward positive attitude support each other. Akbaba et al. (2014, p.220) and Özkal, Güngör and Çetingöz (2004) pointed out the importance of students' curiosity, interest and attitudes in their research on university students' attitudes toward revolutionary history. Likewise, Çelikkaya $(2015$, p. 39) emphasized the reason for the positive attitude towards the social studies lesson. Unlike in the research, the emergence of "general cultural knowledge" in positive attitudes towards the civilization history lesson can be attributed to its specific content. Because, as Sjoquist (2006, pp. 36-38) stated, Civilization history is a field that provides general culture.

The students who stated negative attitude toward civilization history lesson stated that the reason of this negative attitude is "I do not like the civilization history lesson because it makes the student passive" and in the undecided attitudes, "my love for the civilization history lesson varies depending on the subject of the lesson". Quantitative data on negative attitudes towards the civilization history lesson support the qualitative data in large part. McGowan, Sutton and Smith (1990) have linked the negative attitudes of students toward the social studies lesson to the method and technique of teaching as supporting research findings. In the research conducted by the researcher, it was detected that the result of the unsuitable of teaching method and technique made the student passive. As a matter of fact, Ulusoy (2009, p. 430) and Tuncel (2016) have determined that students want to participate actively in class in history lessons.

12 of the students who participated in the research stated that they have difficulty in learning of the civilization history lesson during the interview. They have explained the reason for the difficulty in learning the civilization history lesson because of "the subject is too much". Quantitative data on this cause supported qualitative data. Akengin and Demirsoy (2011, p.11) and Çelikkaya $(2015$, p.39) found similar causes in their research.

9 of the students who participated in the questionnaire stated that they did not have difficulty in learning the civilization history lesson during the interview. However, they stated their reasons as "Undecided" in the applied questionnaire. Although there is no opposition between qualitative data and quantitative data on those who do not have difficulty in 
learning the civilization history lesson, they have not supported each other. Likewise, 5 of the students who participated in the research stated that they were partially compelled to learn the civilization history lesson during the interview. However, in the questionnaire applied, the responses of the students to the reasons related to the partial struggle to learn was mostly "Undecided". It is understood that the reasons that the students indicated in the qualitative data are not supported by the quantitative data. Therefore, in the survey, the reasons why students are interested in the difficulty and partly difficulty in learning the civilization history lesson in qualitative data, can not be generalized to quantitative data.

The students who participated in the research stated the study techniques they applied in the civilization history lesson as source books, course instructors, taking notes and writing them. These qualitative data are supported by quantitative data. In the quantitative aspect of the research, Students answered "Undecided" to work by doing research $(\mathrm{f}=3)$ and "Undecided" to work by doing again $(f=3)$. If these data are considered to have low frequency values found in the qualitative data, it can be considered that the correspondence in the quantitative data is also meaningful. On the other hand, Akbaba et al. (2014, p.220) found that university students read a limited number of books in the history lesson, paralleling the finding of working with multiple books on history lesson.

In the research, the students, in qualitative data, listed the reasons of topics they have learned easily as interest and curiosity, national history and previous information. These reasons are supported by quantitative data. The research and teaching methods and techniques, which are other reasons mentioned in the qualitative data, can not be supported by quantitative data. The study of Celikkaya $(2015$, p. 39) on reasons for easy learning of topics, interesting and fun is parallel to the qualitative findings of this research. The study of Celikkaya $(2015, \mathrm{p}$. 39) on reasons for easy learning of topics, interesting and fun is parallel to the qualitative findings of this research. The reason for the students to learn some subjects easily is that they have knowledge in the issues related to the national history and they regard them as a source of national pride. Another reason why subjects are easy to learn is "prior knowledge". According to constructivists, learning occurs when students use prior knowledge (Grant, 2003, p.88). Prerequisite learning is influential in the ease or difficulty of learning subjects (Engin, Özen and Bayoğlu, 2009). The result obtained in this context is very meaningful.

The students explained the reason for their difficulties in learning some subjects in the civilization history lesson as a "the subject being too much". Other reasons why students have difficulty learning subjects stated in qualitative data not supported by quantitative data. Akengin and Demirsoy (2011, p.11) and Celikkaya (2015, p.39) have found similar reasons such as the fact that the topics are difficult to learn and difficult to understand in their researches. Similarly, Harris and Haydn (2006, p.329) pointed to the importance of flexible curriculum for lesson curriculum. Both students and teachers think that the lesson curriculum is a problem in history teaching (Bal, 2011).

The students stated the reasons of success in the civilization history lesson in qualitative data as teaching method and technique, interest and curiosity, repetition and studying in class. All the indicated reasons are supported by quantitative data. The reasons for failure in the civilization history lesson are stated by the students as teaching method and technique, interest and curiosity, excessive number of topics, inability to create chronology, lack of previous information and no repetition in qualitative data. All the reasons presented by the students in qualitative data are supported by quantitative data. In the research, students have expressed mostly reason of success and failure as the teaching methods and techniques. Harris and Haydn (2006, p.329) emphasized the importance of the curriculum and the teaching method and technique for students in history lessons. On the other hand, the role of the teacher as well as the teaching method and technique is also an important factor (Köse, 2017). When the subject matter of the civilization history lesson, is considered, it is a fact that the subject of this course is much more than the other history courses. So in order to be successful in this lesson and to enjoy it, it is understood that the themes and interactive teaching methods to be formed in the direction of the students' interests are much more important than the emphasis of the students on the events and chronology. Students stated that one of the reasons for success in the civilization history lesson is "to study the lesson". In a study by Booth (1993, p.234) supporting the conclusion of this research, university students have largely attributed their success and failure to their efforts in their research.

The teaching methods and techniques recommended by the students in the qualitative data of researching in the civilization history lesson are such as story-style expression, student-centered teaching, question-answer, the teaching of events and deduction method. All students perspectives on teaching method and technique obtained from qualitative data are supported by quantitative data. Akbaba et al. (2014, p.222) reported that university students had demanded conferences, panels and symposiums for lesson activities and they had not demanded lectures for lesson activities. In the research conducted, the students demand the teaching methods and techniques to make the students active. Moreover, as mentioned above, the students who develop negative attitudes towards civilization history course in the survey explain the reason of these negative attitudes because of "making students passive". When all the data are taken into consideration, it can be considered that the result obtained from the research is meaningful. Fuoco (1996) on the findings of teaching methods and techniques in research argues that stories are an effective approach to the teaching of 
civilizations. In addition, in the study of the Kuzgun and İncili (2016, p.173), the students demanded to stories to the lessons. On the other hand, storyteller narrative helps students to enjoy regardless of their age, and allows them to focus on the lesson (Goodwin, 2006, p. 28). Regarding the teaching of the research findings and the method of total deduction, Bard (1986) suggests teaching and comparing issues such as the successes of civilizations, interactions, and agricultural change. Similarly, Miller and Stearns (1995) planned the teaching of civilizations as a comparative teaching through political, economic, social and cultural themes. In addition, according to Garg (2007, p. 77), a lesson on political, economic, social and cultural themes also provides a perception in the chronology of events. On the other hand, İskender (2007, p. 637) and Şimşek (2010) indicate that historical events are related to today's political, social and economic events.

The teaching materials which are mentioned in the qualitative data of the research and proposed by the students to be used in the civilization history lesson are; Documentaries, films, powerpoint presentations, pictures and photographs, models and chronology charts. All the suggestions obtained in the qualitative data on the teaching material are supported in quantitative terms. The results of the research show that in general students want to use computer technology effectively as teaching material in history lessons. Doppen (2004) research found that students enjoyed the use of computer technologies in history lessons. The results of this research are very similar to the research of Ulusoy (2009). Ulusoy (2009) finds that students want to use different materials such as date (time) bands, map, film, documentary, slideshow. As a matter of fact, using visual materials improves the learning of students (Öztürk, 2010, p.88). However, in some studies, it was found that the use of visual materials in history lessons was found to be low (Aslan and Turan, 2016). In addition, the films that the students offer for the lesson are remarkable. Because historical films increase the students' awareness (Öztaş, Anıl, and Kılıç, 2013). On the other hand, the interactive nature of computer technology provides students with control over their learning (Doppen, 2004, p.272). Information and communication technologies (ICT) in history lesson offer student opportunities (Haydn and Counsell, 2003). Both students and teachers emphasize the use of contemporary teaching techniques and materials in their history lessons and active methods of processing them (Ata, 2007). On the other hand, it has been stated that university students do not use other teaching material in history lesson (Akbaba et al., 2014, p 222; Gülmez, 2003, p. 1071; Kuzgun and İncili, 2016, p.173). In this research, students have suggested the use of diverse and visual teaching materials in history lessons. It can be said that the results of the research are in parallel with other researches when it is thought that the students made opinions on the use of a wide variety of teaching materials.

The students who participate in the research are the activities that they recommend to use in the civilization history lesson in qualitative data; Drama, museum tour, preparation of presentations of students and conference of experts. All findings obtained in qualitative data on the activities suggested in the civilization history lesson were also supported in quantitative terms. It has been determined that drama technique is an effective method in the teaching of ancient history lesson topics in parallel with the results obtained in the research (Kartal, 2009). It is emphasized that activities such as structures and museum trips are fun to learn about school extracurricular activities found in the research (Ata, 2002; Avc1 and Öner, 2015; Kuzgun and İncili, 2016, p.173; Mountford and Price, 2004; Safran and Ata, 1998; Yeşilbursa, 2008; Y1lmaz and Şeker, 2011).

Based on all the results, it is understood that the findings obtained from the qualitative data are supported by the quantitative data. Because the students reported opinions from the interviews at the level of "I agree" and "I completely agree" in the questionnaire. This result has a positive effect on the reliability and validity of the study. Thus, it can be assumed that the qualitative data obtained in the research reflect and generalize the general tendency.

\section{References}

Akbaba, B., Demirtaş, B., Birbudak, T. S., \& Kılcan, B. (2014). Prospective history teachers views about the teaching of Ataturk's principles and history of revolution. Zeitschrift für die Welt der Türken/Journal of World of Turks, 6(2), 207-226.

Akengin, H., \& Demirsoy, M. (2011). Views of the $4^{\text {th }}$ and $5^{\text {th }}$ grade students on social studies course. Marmara University Atatürk Education Faculty Journal of Education Sciences, 33, 5-23.

Aslan, H., \& Turan, İ. (2016). History teachers' level of visual material use. Kafkas University Journal of the Institute of Social Sciences, 18, 347-361. https://doi.org/10.9775/kausbed.2016.018

Ata, B. (2002). Teaching history with museums and historical places: The views of history teachers on "museum education”. (Unpublished master thesis). Gazi University, Ankara, Turkey.

Ata, B. (2007). The approaches of experienced history teachers and prospective history teachers towards a high school student who doesn't like history. Turkish Journal of Social Research, 11(2), 30-42.

Avc1, C., \& Öner, G. (2015). Teaching with historic places social studies: social studies teachers' views and 
recommendations. Abant Izzet Baysal University Journal of Faculty of Education, 15(1), 108-133.

Bal, M. S. (2011). A comparison of views of in-service and pre-service teachers on problems of history teaching and solutions for these problems. Mustafa Kemal University Journal of Social Sciences Institute, 8(15), 371-387.

Bard, I. (1986). Sequencing the writing of essays in pre-modern world history courses. The History Teacher, 19(3), 361-371. https://doi.org/10.2307/493378

Booth, A. (1993). Learning history in university: Student views on teaching and assessment. Studies in Higher Education, 18(2), 227-235. https://doi.org/10.1080/03075079312331382389

Braudel, F. (1996). Grammar of civilizations. (A. Kılıçbay, Trans.). Ankara: İmge Publishings.

Çelikkaya, T. (2015). Student views regarding social studies instruction and education. Journal of Educational Science, 3(4), 30-46.

Collingwood, R. G. (1996). The idea of history. (K. Dinçer, Trans.). Ankara: Gündoğan Publishings.

Creswell, W. J. (2017). A concise introduction to mixed methods research. (M. Sözbilir, Trans.) Ankara: Pegem Publishing.

Demircioğlu, İ. H. (2006). High school students' views on the purposes of history lesson. The Journal of Educational Sciences, 4(2), 153-164.

Doppen, F. H. (2004). Beginning social studies teachers' integration of technology in the history classroom. Theory \& Research in Social Education, 32(2), 248-279. https://doi.org/10.1080/00933104.2004.10473254

Duedahl, P. (2011). Selling mankind: UNESCO and the invention of global history, 1945-1976, Journal of World History, 22(1), 101-133. https://doi.org/10.1353/jwh.2011.0000

Elias, N. (2004). The Civilizing process I. (E. Ateşman, Trans.), İstanbul: İletişim Publishing.

Engin, A. O., Özen, Ş., \& Bayoğlu, V. (2009). Some basing variables influencing the students' school learning sucesses. Journal of the Institute of Social Sciences, 3, 125-156.

Fraenkel, J. R., Wallen, N. E., \& Hyun, H. H. (2015). How to design and evaluate research in education. New York: Mc Graw Hill Education.

Fuoco, J. (1996). An elementary odyssey: Teaching ancient civilization through story (Book) -Book reviews. Journal of Education, 178(3), 99-103.

Gafu, C., \& Trifan, M. (2015). The importance of a multicultural approach in teaching romanian culture and civilization to foreign students. Social and Behavioral Sciences, 203, 217- 223. https://doi.org/10.1016/j.sbspro.2015.08.285

Garg, B. (2007). Teaching of History. Rajat Publications.

Goodwin, S. (2006). Learning strategies and approaches. in M. Hunt (Eds), A practical guide to teaching history in the secondary school. (pp. 27-36). London and New York: Routledge.

Grant, S. G. (2003). History lessons: Teaching, learning, and testing in US high school classrooms. New Jersey: Routledge.

Gülmez, N. (2003). University youth's attitude to Atatürk's principles and the history of revolution. Journal of Atatürk Research Center, 19(57), 1043-1088.

Harris, R., \& Haydn, T. (2006). Pupils' enjoyment of history: what lessons can teachers learn from their pupils? The Curriculum Journal, 17(4), 315-333. https://doi.org/10.1080/09585170601072544

Haydn, T., \& Counsell, C. (Eds.). (2003). History, ICT and learning in the secondary school. London and New York: Routledge.

İskender, P. (2007). The attitude of pre-service teachers towards history lesson. Kastamonu Education Journal, 15(2), 631-638.

Johnson, B., \& Christensen, L. B. (2014). Educational research: quantitative, qualitative, and mixed approaches. (S.B. Demir, Trans. Eds.). Ankara: Eğiten Kitap.

Kartal, T. (2009). The effect of drama method on students? achievement in the teaching of ancient history units a sixth grade social studies course.(Unpublished master thesis). Selçuk University, Konya, Turkey.

Ketchum, A. D. (1978). The Teaching of French contemporary civilization. The Modern Language Journal, 62(1/2), 3-10. https://doi.org/10.1111/j.1540-4781.1978.tb02365.x 
Köse, M. (2017). The Role of high school history teachers on university students' attitudes toward history classes. Educational Sciences: Theory \& Practice, 17(4), 1291-1316. https://doi.org/10.12738/estp.2017.4.0297

Kuzgun, M., \& İncili, Ö. F. (2016). View of social studies pre-service teachers on teaching history courses (Kilis sample). Journal of Social Sciences, 6(11), 158-175.

McGowan, T. M., Sutton, A. M., \& Smith, P. G. (1990). Instructional elements influencing elementary student attitudes toward social studies. Theory and Research in Social Education, 18(1), 37-52. https://doi.org/10.1080/00933104.1990.10505603

McNeill, W. H. (2001). A world history. (A. Şenel, Trans.). Ankara: İmge Kitabevi Publishings.

Miles, M. B., \& Huberman, A. M. (2015). Qualitative data analysis. (S. Akbaba Altun \& A. Ersoy, Trans.) Ankara: Pegem Akademi Publishing.

Miller, M. M., \& Stearns, P. N. (1995). Applying cognitive learning approaches in history teaching: An experiment in a world history course. The History Teacher, 28(2), 183-204. https://doi.org/10.2307/494485

Mountford, P., \& Price, I. (2004). Thinking skills, assessment for learning and literacy strategies in teaching history. Teacher Development, 8(2-3), 233-239.

Muijs, D. (2004). Doing quantitative research in education. London: Sage Publications. https://doi.org/10.4135/9781849209014

Özkal, N., Güngör, A., \& Çetingöz, D. (2004). Teachers' ideas about the social studies course and students' attitudes towards the course. Educational Administration In Theory \& Practice, 10(4), 600-615.

Öztaş, S., Anıl, N. K., \& Kılıç, B. (2013). Vocational high school students' opinions about the impact of historical movies or series on raising the interest for history. EJOVOC: Electronic Journal of Vocational Colleges, 3(4), 107-120.

Öztürk, M. (2010). Location perception skill. In M. Safran (Eds.), How is history teach? (pp. 83-95). İstanbul: Yeni İnsan Publishing.

Safran, M., \& Ata, B. (1998). Out of school history teaching. Gazi University Journal of Gazi Educational Faculty, 18(1), 87-94.

Şimşek, A. (2010). Attitudes of primary and social studies teacher candidates toward history teaching in Turkey. International Online Journal of Educational Sciences, 2(1), 181-203.

Sjoquist, D. (2006). Teaching world civilizations: Where have we been and where do we go from here? Interdisciplinary Humanities, 23(1), 36-42.

Spengler, O. (1997). The decline of the West. (G.Scognamillo \& N. Sengelli, Trans.). İstanbul: Dergah Publishings.

Toynbee, A. (1978). A study of history. İstanbul: Bateş Publishings.

Tuncel. Z. A. (2016). Students' views on the place and importance of history of Turkish education course in pedagogical formation certificate programme. Pamukkale University Journal of Social Sciences Institute, 25, 315-329. https://doi.org/10.5505/pausbed.2016.13540

Ulusoy, K. (2009). High school students' views about instruction of history lesson (A case study in Ankara). Çukurova University Institute of Social Sciences, 18(1), 417-434.

Yeşilbursa, C. C. (2008). The use of historical places in teaching social studies. Journal of Turkology Research, 23(23), 209-222.

Yılmaz, K., \& Şeker, M. (2011). Examining views of primary school students on museum visits and use of museums in social sciences teaching. The Journal of İstanbul Aydın University, 3(9), 21-39.

\section{Copyrights}

Copyright for this article is retained by the author(s), with first publication rights granted to the journal.

This is an open-access article distributed under the terms and conditions of the Creative Commons Attribution license which permits unrestricted use, distribution, and reproduction in any medium, provided the original work is properly cited. 